\title{
O DIALÓGO ENTRE GEOGRAFIA E LITERATURA: A REPRESENTAÇÃO DE GOIÂNIA NA OBRA VIVER É DEVAGAR ${ }^{1}$
}

\author{
EL DIALÓGO ENTRE GEOGRAFIA Y LITERATURA: La \\ REPRESENTACIÓN DE GOIÂNIA EM LA OBRA VIVER ES DEVAGAR
}

\begin{abstract}
LE DIALOGUE ENTRE GÉOGRAPHIC ET LA LITTÉRATURE: LA
RÉPRESENTATION DE GOIÂNIA DANS OCUVRE VIVER É DEVAGAR
\end{abstract}

\author{
Andréia Aparecida Moreira de Sousa \\ Professora de Geografia da rede pública municipal de Aparecida de Goiânia \\ Mestranda pelo Instituto de Estudos Sócio-Ambientais da Universidade Federal de \\ Goiás. Rua Narayola, apt ${ }^{\circ}$ 601, bloco Barbados - Residencial Caribe \\ Setor Jardim Luz / CEP: 74915-235 Aparecida de Goiânia-Go \\ E-mail: andrimosa@ig.com.br \\ Eguimar Felício Chaveiro \\ Professor Adjunto do Instituto de Estudos Sócio-Ambientais / UFG \\ Av. Rio Branco, apt ${ }^{\circ}$. 601, bloco 9 - Residencial Dom Felipe \\ Setor Urias Magalhães / CEP: 74575-070 Goiânia-GO \\ E-mail: eguimar@hotmail.com
}

\section{Resumo}

A cidade de Goiânia - objeto da pesquisa proposta - guarda em sua profundeza momentos sociais e históricos intensos, comprometidos com os sentimentos da coletividade que cada ser humano materializa em algum lugar do espaço, sua voz dá vida à cidade e a representa. O autor da obra Viver é Devagar constitui um representante

\footnotetext{
${ }^{1}$ Este trabalho é parte da dissertação de mestrado que analisa a obra Viver é devagar, de Brasigóis Felício (2003), orientada pelo professor doutor Eguimar Felício Chaveiro da Universidade Federal de Goiás (UFG).
} 
da sociedade goianiense. Diante de tantas vozes que uma cidade abriga, parte-se da representação de mundo do autor que retrata um tempo e um lugar urbano com os seus conflitos singulares e coletivos, mas capazes de representar uma sociedade. O cronista ressuscita as tramas vividas no cotidiano de uma cidade por meio dos signos e símbolos.

Palavras-chave: representação, literatura, cidade, tempo, paisagem.

\section{Resumen}

La ciudad de Goiânia, objeto de la pesquisa propuesta - guarda en su profundidad momentos sociales e históricos intensos, comprometidos con los sentimentos de la coletividad que cada ser humano materializa en algún sitio del espacio, su voz da vida a la ciudad y la representa. El autor de la obra Viver es despacio constituye un representante de la sociedad goianiense. Delante de tantas voces que una ciudad abriga, se parte del principio de la representación de mundo del autor que retrata un tiempo y un lugar urbano con sus conflictos singulares y colectivos, más capaces de representar una sociedad. El cronista resuscita las tramas vividas en el cotidiano de una ciudad por medio de signos y símbolos.

Palabras-clave: representación, literatura, ciudad, tiempo, paisaje.

\section{Résumé}

La ville de Goiânia - l'objet de la recherche proposée garde des moments sociaux et historiques intenses, engagés aux sentiments de la colectivite que chaque être humain matérialise dans un lieu de l'espace, et e sa voix donne vie à la cité et la répresente. L'auteur de e oeuvre Viver é devagar constitue un représentant de la societé goianiense. Devant la foule que cette ville abrite, on part de la représentation du monde de l'auteur qui peint un temps et un lieu urbain avec ses conflits singuliers et collectifs, mais capables de représenter une societé. L'auteur faît rennaître les problèmes du quotidien d'une ville en utilisant des signes et des symboles.

Mots clés: représentation, littérature, ville, temps, paisage.

\section{Introdução}

Este artigo pretende trilhar um caminho construído entre a geografia e a literatura. Trata-se de uma tentativa de demonstrar que a realidade está presente na arte, portanto, ela pode ser utilizada para o entendimento da organização de uma cidade e do significado dos lugares e das paisagens. 
Felício (2003) é o autor da obra em estudo, escritor que nasceu na cidade de Aloândia-GO, no dia 13 de julho de1950. Em 1956, seus pais foram residir em Goiânia, no Setor Serrinha. Aos dezesseis anos, conseguiu seu primeiro emprego como vendedor no Bazar do Estudante, localizado em Campinas, bairro da cidade. Trabalhar em uma livraria contribuiu para reforçar o interesse pela literatura. Foi influenciado por autores como Machado de Assis, Castro Alves, Álvaro de Azevedo, José de Alencar, dentre outros.

Aos 36 anos, Felício ingressou na Academia Goiana de Letras, como o seu mais novo integrante, naquela época, e nela permanece até os dias atuais. Atualmente é jornalista e cronista do jornal $O$ Popular. Publicou suas obras em antologia nos idiomas francês, espanhol e ioguslavo. Sua primeira obra, publicada, em 1972, era um livro de poemas intitulado Sermões do ateu, uma edição do Departamento de Cultura. De 1972 a 2007, o autor publicou quarenta obras.

Felício (2003) tem consciência da relevância do papel que o cronista desempenha na sociedade, e de sua contribuição para a ciência. O autor assim define um cronista:

O cronista é aquele que fala do seu tempo. Ele é um servidor do deus Crônus, um deus do tempo, então, como tal compromisso eu tenho que falar do meu tempo e da minha cidade e foi isto que me levou a produzir crônicas, a produzir trabalhos literários tendo como tema a cidade, onde, eu passei minha infância, a minha juventude e vivo os dias de minha maturidade. $\mathrm{O}$ fato de ser jornalista e ser escritor fez com que eu encontrasse na crônica o gênero ideal para traduzir os momentos de vivência que refletem através de minha sensibilidade como eu vejo o crescimento de uma cidade, como eu vi Goiânia se transformar. A crônica é um gênio do hibrido entre a literatura e o jornalismo (entrevista realizada em 18 out. 2007).

Por meio de suas crônicas, Felício (2003) faz uma viagem no tempo, inspirandose nas imagens mentais, comparando-as com aquelas que a paisagem atualmente lhe oferece, e dela extrai significados que a sustentam, revelando as mutações da metrópole goianiense. $\mathrm{O}$ autor contextualiza a paisagem citadina, penetrando incansavelmente no cotidiano de uma metrópole, e ele próprio é um espectador, e por diversas vezes, o espetáculo. 
As crônicas de Felício (2003) revelam um espaço severamente modificado e inclui a vida humana no rol dessas mudanças. $\mathrm{O}$ seu olhar, ao viajar nas paisagens transformadas da metrópole faz um percurso em si mesmo, nomeando, com as suas imagens literárias, os sentidos das mudanças. No mundo das crônicas, a escrita constrói um espaço e permite ao escritor ser livre com o uso das palavras, criando seus próprios símbolos, tornando-se mais uma voz da cidade.

Uma cidade, ao receber migrantes, também acolhe novos símbolos que são trazidos pelos novos moradores. Trata-se de uma cidade que se sobrepõe a outra, ou seja, várias cidades fundem-se em uma única. Para descobrir o passado de uma cidade, depois de muitas mudanças e com a chegada de novos migrantes, a memória passa a ostentar um lugar de destaque, sendo um meio de resgatar a primeira cidade, ou seja, a matriz.

Goiânia passou por um acelerado crescimento populacional em um curto espaço de tempo, Chaveiro (2005) afirma,

que, numa faixa temporal de, apenas, três décadas, viu alterar o quadro de uma vida espacial localizada no campo para sedimentar a vida do espaço urbano. Essa mutação espacial consagrou, junto, uma mutação simbólica amealhamento e apovorando as referências identitárias do sujeito goiano (p. 175).

Em uma cidade, a memória de seus habitantes pode ser utilizada com o objetivo de resgatar as várias faces de uma cidade. Suzuki (2005) retrata que Leminski, em seus poemas, percebe que a cidade não é apenas imagens o poeta conseguiu captar as várias faces de uma cidade, pois, ela é habitada por várias pessoas, cada uma aparentemente com uma face, mas que, pela dinâmica da cidade, deixam revelar várias outras. Conforme afirma Suzuki (2005),

a análise da representação da cidade, em sua obra poética, nos revelou que não há uma só cidade, mas são múltiplas; desenhadas em diversas faces fotografadas em instantâneos que traduzem muito de seu movimento", assinala Suzuki (p. 138). 
Leminski escreveu poucos poemas referente à cidade, mas foi o suficiente para que Suzuki (2005) realizasse uma leitura da representação da cidade em suas obras. O autor assinala:

\begin{abstract}
Das vivências/experiências com a cidade, não só a de Curitiba, mas sobretudo com ela, Leminski cria um universo multifacetado em flashes rápidos e consistentes dessa relação ambígua de amor e ódio, liberdade e limites, reconhecimento e rejeição, extensão do corpo e recolhimento do espírito, encaixe e desencaixe (p. 125).
\end{abstract}

A memória desperta as lembranças por meio dos objetos, do corpo, dos sentimentos, e é a responsável por guardar os fragmentos do cotidiano. A memória reveste-se de importância ao reconstituir a história, ao possibilitar o conhecimento do passado, a compreensão do presente, pois, seus habitantes portam fragmentos da história.

$\mathrm{Na}$ sua viagem pelo espaço da metrópole, a memória auxilia o cronista no constante confronto entre passado e presente. A memória é constituída por marcos que regressam a um determinado tempo-espaço, e que podem ser coletivos ou individuais, mas todos cumprem uma função social e são mantidos vivos por meio da memória.

O tempo causa estranhamento, adaptação, tensão, medo, comodidade, realização. Cada geração tem uma relação diferenciada com o tempo. A relação espaço e tempo tornou-se efêmera com o desenvolvimento tecnológico, e o tempo revela a atuação da sociedade nos lugares. Essa atuação reflete-se no espaço coletivo, e mesmo partindo da individualidade de cada ser, mascara ou liberta as emoções de cada cidadão, que é o espelho da sociedade e tem o poder de aumentar ou reduzir o valor das coisas ou ocultar as faces da sociedade.

Contemplar o tempo consiste em perceber no passado a complexidade da relação entre o homem e o espaço. Assim, é possível existirem paisagens contraditórias, paradoxais, e elas se tornam palco de luta por transformação, por liberdade e por criatividade, o que permite ao escritor, por meio da literatura, representar o cotidiano de uma metrópole.

Existem diferentes possibilidades para analisar uma realidade, e uma porta de entrada deste trabalho é a geografia que percorre o corredor da literatura, permitindo uma representação da cidade, refletindo seus personagens, suas realidades. Utilizo-se o texto de Luiz Alphonsus (1995), incluíndo no quadro A janela da história da arte (1995; apud 
RAMOS, 2002, p. 81-82), na tentativa de mostrar que os meios para estudar uma realidade é um movimento circular, e em cada volta, abre-se uma possibilidade:

Cada corredor possui diversas portas

Cada porta dá para um quarto

Cada quarto se comunica com outro

Cada outro é ele mesmo sem fim

Cada fim recria seu próprio começo

Cada começo traz em si a esperança

Cada esperança em si a ilusão

Cada ilusão é a próxima mentira

Cada mentira cria uma realidade

Cada realidade some como poeira

Cada poeira é um grão

Cada grão é soprado pelo vento

Cada vento vem de um lugar

Cada lugar ocupa um espaço

Cada espaço é a sua própria ocupação

Cada ocupação delimita um tempo

Cada tempo provoca uma espera

Cada espera procura uma solução

Cada solução não é nada em si mesmo

Cada corredor possui diversas portas

Não importa se as palavras semeadas na obra literária nasceram da verdade, da imaginação, das lembranças da representação ou de um pouco de tudo, o que importa é que representa um momento histórico, um tempo e um lugar. A literatura é o espelho da sociedade, e a sociedade influencia e/ou modifica a literatura.

\section{Narrar e explicar: elos entre geografia e literatura}

Um pressuposto é congruente nesta análise: a história é constituída por meio de uma organização social complexa, em que espaço, tempo e paisagem podem constituir na perspectiva do geógrafo, balizas para compreendê-la. Além disso, a arte, pelo viés estético, representa os feitos históricos, imagina-os, ironiza-os. O espaço, objeto de investigação da geografia, é responsável por temporalizar os fenômenos que ocorrem na superfície terrestre. Conforme Almeida (2003), 
o espaço, além de ser produto das atividades humanas, tem múltiplas valorizações e caracteriza-se por atributos funcionais, estruturais e afetivos. Espaço pode ser então, considerado como o lugar onde os homens e mulheres, ideologicamente diferentes, procuram impor suas representações, suas práticas e seus interesses. Cada espaço, tornando-se social, está possuído de símbolos e afetividades atribuídos pelas pessoas (p. 71).

Ao criar os lugares e as coisas, o ser humano desmistifica uma porção do espaço que pode ser reduzido em tamanho, segundo os significados que os signos revelam. A mente fotografa os momentos vividos por uma sociedade inteira e os preenche de significados em um tempo histórico.

A arte materializa, no espaço, os acontecimentos, os desejos e os sonhos. A imagem é um objeto único, uma janela que revela as peculiaridades do mundo. Uma obra de arte permite uma junção do indivíduo com o mundo. De acordo com Vigotski (2001), “a Arte não só dá vazão e expressão à emoção vária como sempre as resolve e liberta o psiquismo da sua influência obscura. A criação artística é uma necessidade profunda de nosso psiquismo em termos de sublimação." (p.15).

A literatura mostra o mundo vivido por seus personagens, suas dificuldades, alegrias, cores e movimentos. Os símbolos e signos surgem por meio de uma subjetividade e estão deambulando e gritando pelas ruas da cidade, esperando que alguém atento os ouça e os liberte para que vivam além do seu tempo. De uma maneira livre, fundada no critério estético, a literatura é, ao mesmo tempo, voz e escuta do mundo.

Os signos e os símbolos vivenciados e expressos no cotidiano, por meio das pessoas que vêem desaparecer diante de si partes de suas vidas ligadas, sobretudo, à questão da subjetividade encontram na literatura um lugar para serem registrados. A subjetividade funciona como um motor que alavanca a vontade de viver, materializando-a nos processos sócio-econômicos.

Benjamin (1985) observa que, com o desenvolvimento do processo sócioeconômico, cultural e político, a arte sofreu várias transformações, acompanhando o desenvolvimento técnico-científico informacional e as regras impostas pelo sistema 
capitalista, refletidos em sua função, voltada atualmente para o entretenimento, reduzindo sua aura.

A sociedade, por meio do sistema capitalista, organiza o espaço geográfico, o que se reflete nas produções artísticas. A arte que se reduz à técnica consagra a penetração do capitalismo no seu reduto, que via sociedade, reprodutividade, leva o critério da fábrica para aquilo que tem como essência e estética a originalidade, a autonomia.

Benjamin (1985) faz uma viagem no tempo para compreender o momento em que a obra de arte perdeu sua aura. A análise realizada pelo autor tem uma importante contribuição para a ciência, pois, ele aborda a arte na sociedade e no processo histórico.

Ao analisar os treze volumes de À la recherche du temps perdu, de Marcel Proust, Benjamin (1985) observa que o autor descreve sua história baseada em suas lembranças e não na própria vivência, pois lembrar é uma forma de extinguir todas as possibilidades de lembranças. Proust, para escrever, transformava os dias em noites, para que os momentos se tornassem únicos e transparentes. Em suas lembranças, Proust buscava os acontecimentos remotos quase que completamente esquecidos. Ao escrever, não tinha preocupação com a estética, sua obra não era planejada, preenchia todos os espaços, assim como a asma que lhe consumia todo o oxigênio, e sua procura constante pelo ar refletia no papel a ausência de espaço. A asma era intrínseca à sua arte.

Proust, segundo Benjamin (1985), quis suprimir todas as possibilidades de lembranças de si mesmo, transportando-as para o presente, ao qual nunca renunciou, libertando-se do passado. Em sua obra, fez uma crítica social à classe alta que excluía o proletariado do consumo. Dessa forma, buscou a verdadeira essência da economia que se mostrava efetivamente excludente. A sua obra estava à frente de sua época.

A memória tem o poder de resgatar as lembranças. Na missão de resgatar a história de vida, o passado une-se ao presente. O passado vivenciado pela memória permite à pessoa buscar suas raízes, reviver as tradições, contar as histórias, compreender as contradições que se desenvolve na organização do espaço e, nesse contexto, o lugar reafirma sua importância de dialogar com o tempo e o espaço.

A memória acumula os diferentes tempos e as características das paisagens, dos lugares, e a intensidade dos sentimentos. As imagens que a cidade emite são as responsáveis por levar Felício (2003) a retornar ao passado e comparar as paisagens. Esta 
torna-se seu objeto de narração, escreve com base em lembranças, mas as intensifica ao mesclá-las com a própria realidade vivenciada no cotidiano. O cronista mostra claramente uma ruptura no tempo, revive as sensações do passado, mas não abandona o presente.

O escritor pesquisado utiliza como cenário da obra Viver é devagar (2003) o dia e a noite. Descreve o cotidiano da metrópole que desfila diante de seus olhos para, assim, dela abstrair todas as sensações e a maior transparência possível. Ele nunca se liberta do passado que o angustia no presente. Sua obra também faz uma crítica à exclusão social em que está inserida a maior parte da sociedade goianiense.

Por isso, a sua literatura é uma representação do real. Sua obra é concreta e tem um corpo que a representa, e, nesse corpo, existe um domínio imaterial em que o autor materializa sua visão de mundo e a expressa por meio de suas fotografias mentais. $\mathrm{O}$ cérebro é máquina viva que processa e decodifica estas imagens, "pois em todos os momentos de vida o homem 'cria': na doença, no sonho e no miúdo do cotidiano de modo a expressar seu Pathos - o sofrimento, a paixão, a possessividade, que brota em desmesura, enfim, o que é vivido." (PERSICANO, 2002, p. 181).

A literatura tem o poder de identificar os signos e os símbolos que permeiam as relações sócio-econômicas, políticas e culturais, nos momentos vividos. Por meio da literatura, o ser humano cria o seu mundo e o representa no cotidiano. Livre do funcionalismo conceitual, a imaginação literária pode revelar o mundo que a mente guarda e esconde. Procedendo assim, faz o real ressurgir geralmente como alumbramento, encanto, perplexidade, ironia, humor, etc.

A literatura expressa na obra de Felício (2003) baseia-se em seu lugar vivido e se estende por toda a cidade. Seu olhar capta várias contradições que se desenvolvem no espaço urbano. As suas crônicas retratam a vida cotidiana, cujos temas estão presentes nas metrópoles dos países periféricos, tais como: a periferia como lugar de miséria, de violação da vida, de gravidez precoce, o populismo eleitoral, a autodestruição da juventude, a sociedade doente, os menores abandonados, e, também, como é locomoverse de ônibus em uma metrópole.

A crônica Fonte da juventude, constante na obra de Felício (2003), contempla palavras-chave do dia-a-dia de uma metrópole, como correria frenética, formigueiros humanos, tempos assassinos e destruição do planeta azul. Essa longa enumeração apresenta um grande desafio: como percorrer esse vasto mundo social, que é a cidade? 
Antes de iniciar esse percurso, algumas indagações apresentam-se como a crônica literária representa a cidade? Quais são as faculdades próprias da literatura para encadear a representação? Que mundo está representando?

Em suas crônicas, Felício (2003) narra o crescimento de uma metrópole, que representa a morte de sua infância e dos seus desejos, que, voltada para o desenvolvimento tecnológico e o processo de migração, reestruturou a paisagem com a marca do moderno, mas mantendo símbolos de uma tradição rural. O passado que mora em sua memória sobrevive em sua obra, e quem a lê pode interpretar o espaço desse passado.

O literato, ao olhar a paisagem, presta atenção no movimento, regressa ao passado, em busca dos lugares de sua infância. Busca explicações para o crescimento de Goiânia, faz críticas ao sistema capitalista que organiza a sociedade por meio do tempo. Em meio a todo o movimento de contradição das relações sociais, ele percebe que não foi somente a paisagem que mudou, houve uma transformação em seu ser, e ele descobre que perdeu algo importante, o agora, o momento.

O cronista deseja não resgatar a paisagem e os lugares de sua infância, ele tem consciência de que isso não é possível, mas almeja resgatar o prazer de viver. Dessa forma, descobre que ele estava sempre esperando o depois. Felício, em sua juventude, não tinha a consciência do tempo, que atualmente está presente. Por isso, a procura incansável no tempo rápido da metrópole, e, mesmo que tudo à sua volta diga que não há possibilidades, ele sabe que até no tempo rápido pode existir um tempo profundo e o rejuvenescimento das células do corpo, porque, para ele, viver intensamente é viver devagar, independentemente do lugar.

O desejo de escrever materializa-se na linha ou entrelinhas de uma obra literária. Nela estão presentes os desejos mais profundos de um escritor, que não permitem que sua existência passe ignorada, mas seja expressão de um momento histórico. A literatura é a junção do real e do imaginário em que fluem os desejos de uma alma profunda. "Os conteúdos da alma profunda, porém não são apenas pessoais. Além da consciência individual, cada ser humano carrega uma consciência coletiva", salienta Santos, W. (1983, p. 46). 
Muitas vezes, as experiências coletivas ou individuais levam o inconsciente a habitar um submundo atormentado pela repressão de sua vida cotidiana, ou então, ele percebe a beleza e a amplitude da vida que desfila diante de seus olhos e busca compreender o mundo que o cerca. Nas entrelinhas de sua obra, Felício (2003) passa por esses dois momentos: quando revive o passado e busca seus resquícios, quando percebe que existem possibilidades de viver o tempo lento em um tempo rápido.

O cronista, ao ver o córrego de sua infância, faz uma análise social, comparando as imagens do passado com as do presente, e percebe pela leitura da paisagem que muitas mudanças ocorreram:

$\mathrm{Eu}$, que tantas vezes, na boquinha da noite, pescava ali gordos e reluzentes bagres, piabas e chorões, espantei-me ao ver homens, mulheres e crianças pescando ainda, no esgoto em que se transformaram em esgoto o rio da minha infância, triste foi ver que seres humanos buscam seu alimento diretamente do esgoto suburbano. (Ou seriam "novos migrantes", atraídos pelo Estado Provedor?) (FELÍCIO, 2003, p. 58).

Felício (2003) identifica-se com as pessoas que pescam à beira do rio. A pescaria não é somente um entretenimento, mas a forma de obter um alimento para saciar a fome dos excluídos. Ele se surpreende que o rio não seja mais o mesmo - está poluído e representa uma ameaça para a sobrevivência humana e questiona os motivos que trouxeram essas pessoas para Goiânia. Vê-se que o cotejamento entre presente e passado faz da memória do escritor o plano perceptivo para criticar o rumo das transformações.

Ao escrever suas crônicas, Felício (2003) parte do individual, questionando sua qualidade de vida e a compara com o passado. Relembrando os lugares e os vivenciando intensamente enquanto escreve, ele também se preocupa com o coletivo, com a má distribuição de renda, com os pobres que vivem à margem da sociedade, como no trecho que se segue:

Que tristes tempos são estes, que jogam trabalhadores rurais na periferia das cidades, e os transformam em vendedores de picolé! Os que vendem algodão doce às crianças mal sabem: a chuva ácida do poder já derreteu a sua humana dignidade. Vejo senhoras, até bem vestidas, escondendo o rosto - pouco a pouco tiveram que engolir poeira, na periferia periférica dos subúrbios. Muitos acabam de "cair do galho", desceram do meio para a base da pirâmide social. São os 
novos Atlas. Como os "pobres de la tierra", agora também carregam nos ombros o peso da recente e inesperada pobreza (FELÍCIO, 2003, p. 118).

Estão expostos em seu texto os problemas relacionados com a migração e as lutas desumanas de indivíduo que procuram se tornarem cidadãos dignos, e, mesmo sem terem uma chance, sonham na escuridão. $\mathrm{O}$ desemprego ou a concorrência desumana imposta pelo capital fazem as pessoas deslizarem pela pirâmide social, sentindo o desespero de verem desfilar diante de seus olhos a perda de sua identidade. O autor continua:

Eu ali era mais um imortal, por não ter um couro onde pudesse cair morto. Ouvindo gemer e ganir o pobre (e rico) povo GoianoBrasiliense, eu pensava em nosso descaminho de população: Quando seremos povo para os políticos? Dia virá, em que os políticos serão povo? Esperando abrir (ou fechar o banco do Brasil), para balanço (se não roubarem a balança), eu pensava no futuro, e tinha medo... (FELÍCIO, 2003, p. 119).

Felício (2003) ressalta o descaso dos políticos que deixam a população abandonada à sua própria sorte. Ele é irônico ao questionar se os políticos terão sempre o poder, e comenta o aumento da marginalidade pela ausência de políticas sociais que têm como reflexo uma população refém do medo. Para ele, os políticos poderiam unirse para reduzir as desigualdades sociais, para que, no amanhã, como cidadãos comuns não se sintam prisioneiros.

Enquanto realiza seus questionamentos, o cronista retorna ao passado à procura de signos de uma Goiânia com uma tradição rural, inocente, calma, em que o tempo era vivido por meio de uma interação com uma paisagem natural ainda presente. Nessa fase, Goiânia era o corpo de uma menina em transformação.

Entretanto, havia nas pessoas o desejo de uma Goiânia urbanizada, com infraestrutura moderna. O autor, porém, sente saudades da menina que o tempo aprisionou, restando apenas fragmentos na paisagem, mas que sobrevive intensamente em sua memória. Na ânsia de alcançá-la e libertá-la, abraça o coletivo, sente-se pressionado pelo tempo rápido e superficial da metrópole.

Olhando os eventos da cidade, sua loucura indomada, a mudança dos espaços, o autor percebe que há o predomínio do tempo rápido sobre o tempo lento. É como se 
dissesse que o tempo vital, cândido para a vida, é o tempo para o sentimento, a cordialidade, a solidariedade, não para a pressa do capital.

Nesse tempo rápido, as relações pessoais tornaram-se secundárias, o capital impõe um cronograma a seguir e salienta que dele depende um futuro promissor. Disciplina e ordem são palavras de uma metrópole moderna e imponente com seus edifícios, shoppings centers e parques. A vertigem do tempo entoa no espaço da metrópole os acidentes, a delinqüência, a insensibilidade. O título do livro Viver é devagar constitui uma tentativa não de resgatar, mas de encontrar o tempo lento que permite um processo de humanização.

É perceptível nas entrelinhas de sua obra que o autor expressa um acúmulo de sentimentos guardados em seu interior, em virtude da pressão exercida pelo tempo rápido, controlado pelo capital. Os sentimentos extravasam-se como um vulcão em erupção, e o magma expelido é composto de saudades, sonhos, desejos, sentidos e emoções.

$\mathrm{O}$ escritor olha o mundo à sua volta, percebe-o, identifica-o, compreende-o e o materializa em sua obra literária, que apresenta uma totalidade, representando uma sociedade fragmentada. É um ser individual reflexo de uma sociedade organizada em coletividade. De acordo com Santos, W. (1983), “desvendar a alma coletiva é o segredo do poder literário. Desse modo, com os pés na totalidade, o escritor se torna fértil e diz alguma coisa valiosa." (p. 35).

Muitos sentimentos transbordam da alma e se materializam nas entrelinhas de uma obra literária, que ocorre no momento em que os personagens retratam a vida real. As projeções que o corpo/mente denuncia a cada gesto/ação realizada, por meio da música, da poesia, da paisagem, da crônica, nitidamente concretizam-se mostrando o desenvolvimento da história em sociedade em um determinado momento.

Felício (2003), em vários momentos, sente-se reprimido, não se identifica com o presente, como se tivesse parte de sua vida furtada. Roubaram o manto que cobria os lugares por onde seus pés caminhavam, produziram ali fragmentos de um mundo que parecia distante, e agora se unifica ao seu. De repente, já não é possível dissociar o novo do velho, não há uma ruptura no espaço, mas ela está dentro dele. 
Essas peculiaridades da obra do autor asseguram que a história de uma obra literária se funde com a história do mundo: "a história seleciona os acontecimentos em termos de importância causal; a literatura narra os acontecimentos em termos de importância humana." (SANTOS, W., 1983, p.41). Poder-se-ia dizer: a história de uma obra revela sutilmente o espaço no qual viveu e que amamentou a sua imaginação literária.

A literatura pode funcionar como um meio de efetuar uma problematização de um dado momento histórico, pois é uma narrativa do cotidiano, pelo qual é possível interpretar a existência dos fatos, criando uma possibilidade para a compreensão da realidade.

A literatura é uma das formas que o ser humano encontra para manifestar seus mitos, protestos, angústias, alegrias e eternizar uma memória histórica, social, cultural, filosófica e religiosa, pois as obras literárias têm o poder de dar movimento, som, cor e interagir com o cotidiano. E, tal como na obra analisada, há nos textos uma geografia imaginária da metrópole, uma espécie de museu simbólico da cidade, constituído pela memória e percepção do escritor.

A leitura da realidade é realizada por meio da percepção, que é uma janela aberta para o mundo. A literatura permite ao leitor ver o mundo com os olhos dos escritores que descrevem a realidade com base em valores e no momento histórico que vivenciam. Lefebvre (1991) defende a importância da escrita:

A escrita escuta a profundeza e só a tolera se for transparente e perfeitamente penetrada. Não é mais uma cilada para agarrar as profundezas, é o lugar por excelência. [...] $\mathrm{O}$ escritor o revela, desmascara, descobre. Ele o mostra cada vez menos tolerável e muito pouco interessante; mas ao mesmo tempo torna-o interessante pela maneira de dizê-lo, de pô-lo em forma: pela escrita (literária) (p. 16).

A escrita é a voz do escritor que descortina o lugar, apresentando suas peculiaridades individuais e coletivas. A escrita faz-se ouvir nas páginas dos livros que revelam o lugar com o olhar de dentro ou de fora, que esclarece os mistérios ou os criam por meio do cotidiano. Na escrita que ocorre por meio da percepção, é possível realizar a leitura de um determinado momento histórico, ou iniciar a construção da identidade.

Com a percepção, acontece o processo de humanização dos seres humanos por meio do desenvolvimento da sensibilidade. A percepção aciona a memória por 
intermédio dos sentimentos. Em um primeiro momento, a memória faz parte do senso comum, e, em um estágio mais avançado, é capaz de explicar as contradições de uma sociedade por meio da razão.

Vale apregoar que a percepção é umas das formas que o ser humano utiliza para conhecer o espaço em que vive. Por meio dos órgãos dos sentidos, ele interage com o espaço geográfico e o transforma, ou o utiliza para reviver as lembranças do passado.

O escritor pesquisado, ao relembrar o rio de sua infância, vê em sua memória a circulação de pessoas, mas sobretudo o olfato intensifica a sensação de nostalgia, com os odores que o transportam ao passado. Esses odores estão relacionados com o crescimento desordenado da cidade: "Hoje corre pela terra, como fétido esgoto, o rio de minha infância, onde dei abissais mergulhos na leveza de ser pobre e livre menino de rua, em um tempo que ainda havia flores, pássaros, e quintais." (FELÍCIO, 2003, p. 58).

A profundidade do odor permite a revelação de paisagens. Santos, M. (1988) relata a importância desse quesito na realização da leitura da paisagem. Se há várias paisagens na metrópole inquieta, há, necessariamente, vários odores, os córregos e rios, dos hospitais, dos shoppings centers, dos prostíbulos, dos bares, das ruas empoeiradas ou aturdidas de automóveis...

Para Marx (1979), os órgãos dos sentidos representam a prática, são percebidos como órgãos sociais, responsáveis por fixar o ser humano a sua realidade. Nas palavras do autor,

a formação dos cinco sentidos representa o trabalho de toda a história do mundo até hoje. [...] $\mathrm{O}$ homem cheio de preocupações, necessitado, não tem sentido para $\mathrm{o}$ mais belo espetáculo. $\mathrm{O}$ comerciante de minérios apenas atende ao valor comercial dos minérios, não se apercebe da beleza, nem da natureza particular do mineral; não tem o sentido mineralógico (MARX, 1979, p. 25).

O ser humano aprende o mundo pela percepção, mas o capital tem influência sobre os sentidos, e não deixa perceber a beleza do mundo que o cerca. O tempo é visto como lucro, e as pequenas coisas perdem-se, como o colorido natural da paisagem, os animais, o sol, as relações com o lugar e com a família, não sobrando tempo para analisar as mudanças dos lugares das vivências humanas. 
Felício, como escritor, não permitiu que roubassem de sua mente os valores, as sensações de liberdade, a sua história, que na realidade é a história da sociedade. Os seus órgãos dos sentidos representam os órgãos sociais. Essa é a importância da literatura: permitir que o escondido do sentimento se revele, se expresse, servindo para robustecer a análise da ciência.

A percepção está impregnada de valores reflexos da sociedade na qual se vive. Felício (2003), em sua obra, realiza a leitura de Goiânia com base em valores e suas vivências. A literatura tem o poder de revelar como cada ser interpreta e expressa o meio em que vive, e, para tanto, o autor descreve suas ações e as projeções que ele recebe do seu mundo externo, concretizando sua existência por meio do lugar e do momento em que ocorrem.

Ao realizar a descrição do espaço vivido, o autor expõe seus sentimentos e sua visão do espaço geográfico em um processo construtivo, dinâmico, e dialético. Conforme Vigotski (2001), “o psiquismo do homem social é visto como subsolo de todas as ideologias de dada época inclusive na Arte." (p. 111).

A arte tem autonomia relativa diante da realidade, e está relacionada com a possibilidade da comunicação, da técnica e da materialidade do real. Todavia, com essa autonomia relativa, enxerga o que é difícil para os programas científicos, acostumados pelas suas balizas geralmente repetidas.

A literatura, portanto, propicia novos sentidos e significados para a leitura da paisagem, expressando qualidades de um tempo e de um espaço como atributos de sua faculdade de criar e ser. Pertence, portanto, a outra temporalidade.

A arte produz um mundo, uma totalidade que se articula e sobrevive por si mesma, ainda que possa ficar esquecida ou ignorada durante anos. O seu poder de revelar a universalidade humana reside exatamente na sua capacidade de enxergar o sutil.

Uma obra de arte pode surgir de desejos, dos sonhos, da imaginação, mas tudo isso pode representar um mundo real, é uma forma de dar expressão e criatividade à obra de arte que se constrói no interior de uma realidade. De acordo com Persicano (2002), 
a criação humana sempre foi identificada, pelo homem, com as artes e é possível afirmar que a expressão criativa artística é uma espécie de sinal ou sinônimo de humanidade. Tem um pé apoiado na irracionalidade e salta para a razão a partir da realidade do outro. (p. 181).

As obras de arte fazem parte da história. O ser humano sempre criou novas formas de representar o espaço por ele usufruído. Nessas representações, ocorre a junção do real com a imaginação - o que é, o que foi e como poderia ser. O confronto entre a razão e a emoção permite ao ser humano construir o espaço e o tempo em que vive.

A sociedade é quem determina e age sobre os seres humanos. Uma pessoa por si só não representa a sociedade, mas é representada por ela. Felício, aparentemente, é um único ser, mas a sua constituição como ser antecede o presente, representa o momento, com uma bagagem que o acompanha antes mesmo de sua existência, trazida pelos seus ascendentes.

O cenário em que o cronista realiza o seu trabalho empírico é uma cidade que ele viu se transformar em metrópole, sendo ele o espelho da sociedade que absorve e reflete os seus movimentos. Sua memória armazena imagens que caracterizam a dor, o medo, o desespero, o entusiasmo, a alegria, o fracasso, a destruição, levadas à superfície pela recordação, vivência ou observação dos lugares por onde seus pés deambularam.

Essas imagens, com seus significados, representam a verdade, resquícios de seu cotidiano que consagrou sua obra literária. Santos, W. (1983), a esse respeito, salienta que em toda obra literária existe uma verdade humana. Ao realizar uma leitura, se não for possível encontrar essa verdade, o livro deverá ser lançado ao fogo, e não ser reverenciado.

A literatura tem autonomia para diagnosticar as causas e os efeitos que as contradições desenvolvidas no espaço urbano têm sobre cada ser, e como eles lidam com os reflexos e o representa em seu mundo exterior, "porque a literatura é o exame do homem." (SANTOS, W., 1983, p. 47). O autor continua:

A Matemática é mais valiosa quando justifica a presença do homem no mudo; a química é mais valiosa quando ajuda compreender mais o homem. A Ciência da Literatura, todavia, tem um dever básico de se transformar em ciência do homem. Porque não se encontra, na obra 
literária, outra coisa que não seja o homem: ele é o que se constrói em som, palavra, frase, sentido, história, sociedade, consciência, espírito, visão. Retirando o homem do centro do literário, sobram simplesmente alguns resíduos técnicos. Embora tais resíduos tenham adquirido grande importância na poética formalista, eles constituem, quando elevado ao primeiro plano, a força maior da desumanização da literatura. Desumanização instaurada a partir do momento em que se dá o esquecimento da função essencial do literário: ser um exame do homem (SANTOS, W., 1983, p. 147).

No desenvolvimento da análise geográfica, muitas obras literárias podem revelar seu conteúdo, pois transmitem significado às relações humanas e as estabelecem no corpo da obra em estudo, em que a cidade apresenta e representa a sociedade que a criou. As paisagens descritas nas crônicas refletem os valores, os gostos, os desejos, ou seja, o meio no qual circula e vivencia. Felício (2003) descreve a miséria de muitos, a dor dos oprimidos, que estão ora à margem da sociedade, ora no centro das discussões, para levá-los de volta ao lugar de origem, demarcado pelo mundo capitalista.

Por meio da literatura, pode o ser humano compreender, resgatar e vivenciar intensamente um período histórico distante da realidade que o cerca. Para isso, o poeta utiliza os seus cinco sentidos que funcionam como ferramentas na construção desse percurso, e a mente do leitor penetra e participa ativamente da construção do processo histórico. "Não é preciso entender de cavalos para reviver os dramas da corrida de Wronski”, assinala Lukács (1968, p. 77).

A literatura funciona como um reflexo do mundo contemporâneo; é o espelho da sociedade refletindo as tramas vivenciadas no cotidiano de uma cidade. O olhar do cronista representa uma máquina que filma, descreve, narra, as contradições de uma sociedade e as representa em sua obra. Monteiro (2002) expõe que

na coletânea dos geógrafos britânicos, as 12 análises no campo da literatura assentam no princípio básico de que - excetuadas a ficção científica, a fantasia e a alegoria - a noção de "lugar", embora sendo obra de imaginação e criação literária, contém uma "verdade" que pode estar "além" daquela advinda da observação acurada, do registro sistemático de fatos. Esta capacidade paradoxal encontrável na literatura, ou a ela conferida pelo geógrafo, brota de um reconhecimento de que a essência ou a verdade do mundo transcende á interpretação de dados coligidos por geógrafos, historiadores e sociólogos. Não se trataria, de nenhum modo, de substituir a análise científica pela criação artística, mas apenas retirar desta (Literatura) 
novos aspectos de "interpretação"; reconhecê-la como um meio de enriquecimento (p. 14-15).

Por isso, a geografia pode valer-se da literatura como uma fonte de pesquisa, é um documento que revela importantes fatos permite compreender uma cidade. Enfim, nesse trabalho, a pesquisadora é uma leitora atenta, em busca de símbolos, pistas que a ajudem a compreender as mudanças ocorridas na metrópole goianiense.

\title{
Representação: espelho da sociedade
}

A imagem de uma cidade é alterada ao longo do tempo. A representação percorre o caminho da memória que traz à superfície o espaço vivido. A obra Viver é devagar, de Felício (2003), é o ponto de partida para uma análise da cidade com base na representação revigorada na memória do cronista por meio das suas lembranças.

Felício (2003), em suas crônicas, ressuscita a memória da cidade. As suas representações surgem de seus desejos de compartilhar as mudanças histórico-sociais, ou seja, da necessidade de narrar as transformações que ocorreram nos lugares por onde seus pés caminharam, o que confere originalidade ao seu estilo artístico.

A obra Viver é devagar (2003) permite fazer desfilar uma mistura do imaginário, mas é também fruto de um mundo real em que o escritor é o reflexo da sociedade, à qual empresta os seus cinco sentidos, conectando corpo e mente aos movimentos do mundo. De acordo com Rodrigues, M. (2003),

\begin{abstract}
devemos considerar dialeticamente "o social como fator interno à produção literária" buscamos, nas reflexões em que temas dessa natureza estão em pauta, os fundamentos balizadores do processo de construção do conhecimento e da produção artística, objetivando construir para a construção de um saber geográfico sintonizado com a nossa realidade (p.90-91).
\end{abstract}

A cidade é o palco no qual se desenvolvem as tramas do cotidiano. A sociedade participa diretamente da produção literária com as imagens que afluem para a construção do lugar em que o poeta vive, observa e analisa, materializando-o em uma obra literária, que, por meio de seus personagens, ou de si mesmo, ressuscita as tramas 
de um cotidiano distante, nos permite compreender a realidade. O poeta constrói, assim, um saber geográfico em que sua história é a história da sociedade.

Analisar uma obra literária por meio do desenvolvimento histórico-social é uma forma de adentrar sua essência, pois os sentidos sociais são despertados à medida que aumentam as desigualdades entre as classes sociais. A representação social constitui o instrumento essencial para obtenção do resultado da análise. Miranda (2006) expõe:

A representação social é constituída em um processo que envolve o sujeito e o contexto social de suas experiências, mas não pode ser entendida como se fosse uma cópia fiel do que é representado. Contudo não se difere totalmente do objeto a que se remete. Na representação social se estabelece uma dinâmica que envolve o sujeito e o contexto sociocultural em que está inserido (p. 29).

A representação permite conhecer o universo urbano, e dela fazem parte o imaginário, a memória e os significados que a mente absorve das imagens vividas e imaginadas. A representação é a realidade da existência do ser humano que tem a capacidade de mostrar os meandros da mente na captura de um espaço que possa ser chamado de seu.

Para Moscovici (2003), representar não é somente uma forma de compreender o mundo, mas também de se comunicar e de interagir. $\mathrm{O}$ autor chama a atenção para os diversos tipos de linguagens que surgem por meio dos símbolos, que são impostos, criados, recriados, destruídos e transformados pela sociedade. No entanto, fazem parte de uma linguagem que une e separa os grupos sociais: "representação = imagem/significação; em outras palavras, a representação iguala toda a imagem a uma idéia e toda idéia a uma imagem.” (MOSCOVICI, 2003, p. 46).

A representação é uma forma que permite entrar em contato com o mundo. Para tanto, criam-se imagens que são desenvolvidas por meio de uma linguagem. As lembranças que emergem de um passado distante ou remoto são importantes para a construção e desconstrução de novos símbolos. E, nesse momento, o imaginário desempenha um papel essencial, pois é uma forma de assimilar o mundo exterior em seu interior.

A representação de Felício (2003) é reforçada por meio de uma leitura ligada à tradição, que o condiciona e o aprisiona em uma temporalidade outra, como uma fuga 
da realidade que o cerca. A leitura que o cronista realiza faz parte dos estímulos que a sociedade lhe transmite e ele os devolve mediante representações que são as respostas emitidas a sociedade. "As representações, ou modos de pensar, atravessam a sociedade exteriormente aos indivíduos isolados e formam um complexo de idéias e motivações que se apresentam a eles consolidados", afirma Reigota (2007, p. 68).

Nas representações criadas por Felício (2003), os personagens são dinâmicos, reafirmam a divisão de classes sociais e os preconceitos e dificuldades vividos pelo proletariado. O poeta frustra-se com a realidade que o cerca, com a desordem que domina sua cidade de infância. Mostra as várias faces de uma cidade e sente as injustiças sofridas pelos pobres, sendo ele próprio um injustiçado.

O cronista não fala com mediocridade da vida suburbana, mas, por meio de seu olhar, tenta encontrar sua beleza. Seus personagens são pessoas simples que habitam uma cidade que cresceu acentuando a diferença entre as classes sociais. Na verdade, ele descreve o seu próprio cotidiano e a realidade que o cerca, mas um grupo pode ser identificado com ele. Em nenhum momento ele se sente superior. Cria por meio da sua realidade o seu próprio estilo.

O estilo provém da sua forma de olhar o mundo que o cerca e das imagens que são projetadas dentro e fora de sua mente. Dalcastagné (2002) e Almeida (2003) demonstram a importância do olhar. O olhar expressa à cultura a identidade, a forma de dar significados as coisas, o preconceito em relação ao outro lugar, ou seja, as diferenças que existem no olhar de fora e de dentro. É uma forma de perceber as contradições presentes nas obras literárias brasileiras e nos textos científicos. $\mathrm{O}$ olhar define uma obra, mas ela é o reflexo da cultura de quem a observa.

O olhar do cronista capta não somente a beleza de uma metrópole, mas também as diversidades e conflitos sempre em movimento. Almeida (2003) define o olhar como “o ato de contemplar a natureza, não é um atitude natural. Pelo contrário, ele é resultante de uma instituição da cultura que inventou essa contemplação e lhe deu uma significação e valor.” (p. 72).

Como resultado de seus passeios pela cidade, os olhos de Felício (2003) tornamse experientes, acompanham a transformação de sua cidade e observam uma cultura sendo sobreposta à sua; os seus olhos são a prova viva desse acontecimento. O poeta 
olha e vê a cidade carregada de violência, desprovida de sentidos, mas, por outro lado, tenta dar um significado à sua própria vida.

Felício é um representante popular, sendo ele próprio um personagem presente e ativo em sua obra. Enquanto desempenha seu papel de narrador, denuncia a exploração da mão-de-obra assalariada, a corrupção e retrata a dificuldade dos pobres sobreviverem em uma metrópole. Quando um autor é ele próprio o outro, Dalcastagné (2002) o classifica como quem é capaz de mostrar a realidade na "perspectiva de dentro" (p. 62).

A obra de Felício (2003) é uma forma de representar o outro por ele mesmo, ou seja, ele é o outro que ele extrai de dentro de si, é um porta-voz de uma realidade vivida no cotidiano. Seu objetivo não é apenas narrar, mas fazer refletir sobre os problemas vividos na área urbana. A sua obra traz uma perspectiva vinda do seu interior, de dentro, pois "a narrativa é uma arte em evolução, que busca caminhos novos frente a obstáculos novos. Um desses 'obstáculos' é o aumento da consciência sobre as diferentes formas de preconceitos" (DALCASTAGNÉ, 2002, p. 53).

Por mais próximo que esteja de uma realidade, um escritor pode não conseguir representar o seu conteúdo, tendo dificuldade de identificar os símbolos que vê, o que ocorre porque ele tem uma bagagem cultura oriunda de um grupo ao qual pertence. Mas isso não significa que sua representação não seja real. É o mundo do outro visto pelo lado de fora.

Almeida (2003), ao analisar as representações do sertão, utiliza também as expressões de dentro e de fora. Desenvolve seu trabalho pautado em duas concepções: o olhar de quem é externo ao lugar, e o olhar de quem pertence ao sertão, centrado no espaço vivido de seus habitantes. E conclui que um objeto apresenta vários significados, de acordo com a identidade do grupo que o observa ou o utiliza.

Almeida (2003) retrata a importância da representação dos seres humanos para conhecer os lugares e as potencialidades que levam a construção das paisagens, pois “pelas representações também é possível entender a maneira pela qual as pessoas modelam as paisagens e nelas afirmam suas convicções e suas esperanças” (p. 71).

Almeida (2003) propõe uma construção discursiva, um diálogo sobre a representação do sertão entre vários escritores, e chegou a uma conclusão:

as visões de sertão aqui reveladas pelos "de dentro", ele constitui o espaço territorial natural socializado, o conhecido, o nosso sertão; 
para os 'de fora', é um espaço natural ainda não socializado, o 'lá', imaginado e ignoto (p. 86).

Calvino (1990) também chama a atenção para o olhar de dentro e de fora, ao descrever a cidade de Irene. Os olhares demonstram que muitos falam de uma mesma cidade, e a definem. No entanto, ao ouvir diferentes opiniões em alguns momentos até para o personagem Marco Pólo se torna difícil saber se estão falando de uma mesma cidade. Segundo o autor,

os viajantes do planalto, os pastores que transumam os armentos, os passarinheiros que vigiam as redes, os eremitas que colhem raízes, todos olham para baixo e falam de Irene. [...] A esta altura, Kublai Khan espera que Marco diga como é Irene vista de dentro. E Marco não pode fazê-lo: não conseguiu saber qual é a cidade que os moradores do planalto chamam de Irene; por outro lado, não importa: vista de dentro, seria uma outra cidade; Irene é o nome de uma cidade distante que muda à medida que se aproxima dela. A cidade de quem passa sem entrar é uma; é outra para quem é aprisionado e não sai mais dali (CALVINO, 1990, p. 114-115).

Calvino (1990) deixa claro que não existe um olhar certo ou errado ao observar uma cidade, e não importa se o olhar é de quem é de fora ou de dentro. O importante é o que a cidade representa para os sentidos de quem a observa, seja pelo odor, pela brisa, pelo sabor ou pela paisagem que os olhos contemplam. A interpretação ocorre de acordo com os sentidos de quem vê e as relações subjetivas que estão presentes. Por isso, a cada representação uma nova cidade surge, ou uma de suas faces, deixando de ser invisível. Uma cidade em sua essência representa uma unicidade, sem deixar de ser universal.

A análise de Almeida (2003), Dalcastagné (2002) e Calvino (1990) mostra que a forma de olhar uma realidade está diretamente ligada à cultura de quem observa. Como toda regra pode haver uma exceção, dependendo da sensibilidade de quem observa e como o faz, é possível desenvolver a empatia em relação ao lugar e às pessoas e compartilhar suas visões, independentemente da cultura do observador. Ao ler a sua obra, percebe-se que Felício (2003) não teve dificuldades para representar, por meio da narração, os grupos marginalizados, como as prostitutas, as pessoas que vivem na periferia, etc. 
Felício (2003) observa os lugares com o olhar de dentro. São lugares conhecidos, nos quais esteve presente uma socialização, ficando evidente a vontade de resgatar o que o tempo rápido marcado pelo desenvolvimento tecnológico suprimiu de sua vida de forma perversa e silenciosa e o desejo de reencontrar o tempo profundo. $\mathrm{O}$ autor lança um desafio, uma inquietação por meio do título de sua obra Viver é devagar.

Ao visitar uma cidade, ela também é representada, seja pelo impacto das imagens, dos símbolos desconhecidos, ou por meio das identificações. Felício (1974) foi para São Paulo a passeio com alguns amigos, e, ao chegar, ficou atordoado com a quantidade de símbolos concentrados nas principais avenidas e com o grande número de pessoas circulando pelas ruas, o que lhe causava uma sensação de frieza, pois o calor humano se fazia ausente para ele uma cidade desumana. "Olhava admirado para as vitrines reluzentes, apalermado e bobamente estupefato com os aglomerados urbanos formigueiros - da av. São João", afirma Felício (2003, p. 35).

O poeta olhava a cidade com olhar de fora, estava acostumado a viver em um lugar em que as distâncias eram pequenas. Assim definiu São Paulo:

A Paulicéia de Mario da Andrade. Quando vi isso tudo senti vontade de suicidar, ou voltar imediatamente para Goiás. Não agüentaria viver num lugar assim apinhado de gente que não se conhece e nem quer se conhecer (FELÍCIO, 1974, p. 33).

O ritmo frenético era estranho à sua realidade, como se aquelas pessoas tivessem que alcançar algo que só estaria ali naquele instante. Nesse momento, ele não podia imaginar que a sua cidade iria se expandir e seria atingida pelo tempo rápido da metrópole. A sensação de solidão continuou mesmo após alguns dias, pois sentia falta de sua cidade e de relacionar-se com as pessoas, como revela nesse trecho:

Eu sinto uma solidão enorme. Sozinho dentro de São Paulo, [...] Aquela cidade gigantesca e desumana, aquele povo correndo atrás de uma coisa que talvez nem existia. $\mathrm{O}$ burburinho humano eu não podia compreender, que estava perplexo e temeroso do que fosse significar para mim aquela aventura. [...]. Sofria horrivelmente uma solidão horrível, e não pensava se esse sofrimento pudesse redundar um dia em literatura. [...] (FELÍCIO, 1974, p. 34). 
O autor ficou perplexo com os movimentos dos transeuntes, algo que não fazia parte do seu cotidiano. A imagem de São Paulo estava distante de uma cidade considerada ideal em seus conceitos. Essa representação era aparentemente individual, mas fora formada com base em uma contribuição social oriunda de seu lugar de origem. Ele não conseguia perceber São Paulo em sua totalidade, que estava presente no imaginário das pessoas que construíram a cidade, que, para ele, era um mundo fragmentado.

Nas representações, estão presentes os encontros do real salpicados por um mundo imaginário, uma mistura do consciente com o inconsciente, frutos da sociedade em que se está inserido. Afirma Silva (2001):

\begin{abstract}
A representação é dada a partir de um sistema de idéias, seja uma interpretação racional, mística cientifica ou filosófica é construída para entender o mundo. As representações são resultados de um a interação social de relações complexas existentes no interior da cidade por diversos segmentos sociais (p. 79).
\end{abstract}

As representações sociais são formadas por diferentes grupos que ampliam suas influências sobre a sociedade. $\mathrm{O}$ cronista representa uma memória coletiva marcada pela percepção da realidade que parte da sensibilidade. O senso comum pode representar os fatos de forma racional, e Felício (1980) narra os detalhes de seu mundo cercado por destruição e reconstrução, assim como no poema Cidade petrificada, de sua autoria:

Já percorri, com meus olhos de menino esta cidade de pedra

Esta cheia de vida quando menino a habitava.

Por milhões de Neros incendiada, ficou petrificada Não há sentimento que a abale.

Tem uma doença que agiganta seu ventre e devora seus habitantes. Está podre, absurda. 
Seus edifícios nobres:

Palácio Luís de Camões,

Condominio de Versailles.

Só sei dizer dos quintais pobres

onde perdi, sem ter encontrado

as ilusões de menina

A cidade inchou, ficou tarada.

ficou esta miséria - multiplicada.

Nesse poema, o autor busca em sua mente as imagens que seus olhos de criança assimilavam e percebe que a paisagem mudou. $\mathrm{O}$ concreto expandiu-se, e o verde que intensificava a vida se extinguiu. A cidade tornou-se vazia não em quantidade, pois houve aumento de edificações, mas em qualidade. Os prédios multiplicaram-se, as ruas expandiram-se, e as pessoas tornaram-se solitárias, vazias e isoladas, embora com todo o seu tempo preenchido.

Atualmente, os quintais são revestidos pelo concreto de cor cinza, e, nos condomínios, sequer existem. A cidade cresceu, e, com ela, os seus problemas, não somente físicos, como a miséria, a falta de infra-estrutura, a poluição, o excesso de lixo, mas sobretudo emocionais, pois as pessoas perseguem um sonho: viver devagar em um tempo rápido. Esta é a representação que Felício construiu de sua cidade, e a transmite pela sua arte - a poesia.

Suas crônicas narram os acontecimentos de seu tempo. Muitos grupos participaram dessa representação construindo, destruindo, dando vida, propiciando a morte, libertando, oprimindo, proporcionando alegria ou tristeza. $\mathrm{O}$ fato é que o tempo não pára, é único, mas cada ser deve buscar em si mesmo uma forma de interagir com o tempo.

Felício (2003) interage com o tempo por meio da narração, que, em seu desenvolvimento, apresenta o conteúdo que aparece diante dos leitores com suas peculiaridades. Segundo Lukács (1968), o verdadeiro narrador penetra incansavelmente no seu mundo literário, sendo ele os próprios personagens. Os seus sentimentos alcançam o submundo de suas frustrações que se entrelaçam com os problemas da sociedade a qual está inserido, e a eleva com limpidez à procura da vida profunda que se 
esconde em um lugar, que somente a sensibilidade e a inquietação são capazes de encontrar.

Um literato é um observador inquieto, os detalhes são preciosos para a sua narração, e a cidade pode ser sua fonte de inspiração. A cidade oculta-se e, ao mesmo tempo, se revela aos olhos humanos, é representada pelo próprio eu em uma relação com o outro, e com seus conceitos, representam-se outros lugares, outras cidades. Uma representação supõe outra, conforme o espaço sofre metamorfoses. Por isso, uma representação não transgride uma realidade, mas é uma forma de mantê-la viva.

A cidade é o palco das representações que ocorrem na prática do cotidiano ou no pensamento, pelo simples ato de pensar um objeto, ele é o representado na memória. Felício (2003) representa em sua obra o lugar de sua infância, os laços de afetividade e de antipatia, assim fez Rodrigues, G. (1978), ao escrever o poema Regresso. O texto retrata o regresso do autor a Minas Gerais e fica evidente a sua decepção ao visualizar a imagem da cidade onde nascera e passara a infância. $O$ poeta percebeu que as cores não eram mais as mesmas, o verde foi substituído pelo cinza, as formas foram alteradas, surgiram construções verticalizadas, que o impediam de contemplar o céu. O seu mundo estava desintegrado, e a representação de seu lugar só existia em sua memória, como se pode perceber nos versos do autor:

\section{Regresso}

Entrei pela avenida principal do meu pensar e caminhei com dúvida sem saber por que ruas!

Procurei uma casa de fachada natural onde a natureza saudava cada chegar pois era a informação que tinha para encontrar você: Uma grande casa com árvores verdes e pássaros na frente.

Caminhei pelas vilas, pelas ruas e avenidas, procurei casas mansões e apartamentos, encontrei concreto, me cansei do cimento, desapontei-me com arranha-céus que não me deixaram ver a lua.

Voltei triste e com saudades daquela casa, 
com vontade daquela sombra e daquele vento...

Regressei pela avenida marginal sem pensar.

Quanto me assentei, ainda no mundo natural como gosto e tenho,

Não consegui compreender por que aqueles homens

Regaram mais o concreto que as árvores e

Cuidaram mais do cimento que do natural!!!

Regressei triste... Voltei para ficar.

Rodrigues, G. (1978) desejava ver uma casa grande e simples rodeada pela antiga paisagem. E que os pássaros aos quais um dia ele dera adeus fossem a orquestra para desejar-lhe boas vindas. Ele queria sentir o vento abraçar o seu corpo, como nos tempos de outrora. Entretanto, os ruídos o impediam de ouvir a orquestra canora, e os edifícios e sobrados não lhe permitiam mais sentir o vento. Havia uma representação de cidade guardada em sua memória e a nova representação que surgia o entristecia.

Rodrigues, G. (1978), por meio de seus sentimentos e de sua imagem mental, descreveu sua cidade, que passara por intensas metamorfoses no período em que estivera ausente. Segundo Freire (1961), não é possível retornar à cidade natal e encontrar a paisagem e as relações cotidianas que havia antes: "na cidade, a experiência de voltar é decepcionante. O lugar não é mais o mesmo e a possibilidade de desencontro é maior." (FREIRE, 1961, p. 205).

O lugar não é mais o mesmo, mas, nas lembranças de quem recorda, ele não muda, continua repleto de significados que se confrontam com a nova imagem do presente, e permanece dentro de si uma resistência. Mesmo tendo residido na cidade de São Paulo por muitos anos e acompanhado de perto seu desenvolvimento, nota-se uma perplexidade de Rodrigues, W. (1978) ao ver que características de São Paulo em sua cidade de origem, que até aquele momento, estava intacta dentro dele.

A tristeza de Rodrigues, W. (1978) torna-se evidente porque os sentimentos guardados na mente têm maior poder que aquelas que os olhos podem ver. Felício, ao contrário de Rodrigues, W. nunca se afastou de Goiânia, e, mesmo estando presente, não conseguiu acompanhar o desenvolvimento e crescimento de sua cidade. Os dois poetas sentem o mesmo vazio e a mesma saudade de um passado não muito distante, 
como se existissem duas cidades, dois lugares, e há mais que lembranças, há recordações.

A cidade apresenta-se de forma fragmentada. O todo nunca é revelado, sua imagem é como uma obra de arte construída mediante momentos de contradições. Uma cidade como totalidade é única. Em uma cidade, existem várias outras, cujos fragmentos se confrontam com a totalidade e provocam choque ou enfeitiçamento, pois ambas têm a força de unir e de desintegrar.

Um escritor, ao guardar em sua memória os registros dos lugares, o faz como uma filmagem e os deposita em uma obra literária, materializada para o futuro. Morrem o lugar, a cidade, e a vida que ali existia abre as portas para o futuro das representações.

\section{Considerações finais}

Este trabalho representa um esforço de tentar analisar o diálogo entre geografia e a literatura, que permite buscar novos caminhos para realizar estudos referentes ao espaço urbano, com a finalidade de compreender o espaço goianiense por meio de uma obra literária, que representa a metrópole.

Foi realizada uma investigação pautada nas experiências de um autor como observador, e o cenário que instigou a construção de suas crônicas foi, na maioria das vezes, a rua.

A literatura é um dos meios que o ser humano utiliza para compreender as transformações de um momento histórico. A cidade funciona como um laboratório no qual estão disponíveis os signos, os símbolos, as imagens, o imaginário, as lembranças e as recordações.

A memória transporta no tempo as lembranças das paisagens com as quais teve contato, permitindo relembrar vários momentos vividos. Na mente humana, todos os acontecimentos estão relacionados a um lugar e à paisagem que o cerca. Quando a paisagem passa por mudanças, interfere nos sentimentos, gerando apego ao passado por meio dos fragmentos guardados na memória. A paisagem está repleta de representações sociais impregnadas pelo fator cultural e é importante para a construção da identidade.

Os símbolos presentes no espaço urbano chocam-se e/ou se fundem com uma nova identidade que está em construção, permitindo novas representações de um mundo, ora 
rural, ora urbano, de acordo com sentimentos ou necessidades. O ser humano, ao ver o mundo pela janela literária, utiliza a percepção que parte da subjetividade como lembranças que se objetivam no campo social.

Nesse sentido, o ser humano apropria-se do seu objeto também humano e o identifica com base nas relações sociais. O seu objeto é um reflexo de si próprio que se identifica com o universal. A memória percorre um caminho que o escritor vivenciou, ou estudou, resgata os símbolos do tempo presente e os compara com o passado.

A autenticidade da representação reside na contradição, nas certezas e incertezas, na totalidade e na fragmentação. A representação é uma linguagem, uma forma de comunicação, um dos meios para perceber a cidade.

A literatura cumpre um papel social à medida que representa a voz da sociedade. Felício ouve as vozes das lembranças e se comunica com o passado, com o presente e se projeta no futuro, por isso, as crônicas podem ser consideradas um documento que a geografia pretende legitimar neste trabalho, que se encontra em construção, pois, resgatar o passado é construir a memória de uma cidade.

\section{Referências bibliográficas}

ALMEIDA, Maria Geralda. Em busca do poético do sertão: um estudo de representações. In: ALMEIDA, Maria Geralda. RATTS, Alecsandro J. P. (orgs.). Geografia: leituras culturais. Goiânia: Alternativa, 2003. p. 71-88.

BENJAMIN, Walter. Magia e técnica, arte e política. $5^{\mathrm{a}}$ ed. Tradução de: Sérgio Paulo Rouanet. São Paulo: Brasiliense, 1985. (Obras escolhidas, 1).

CALVINO, Ítalo. As cidades invisíveis. Tradução de Diogo Mainardi. São Paulo: Companhia das Letras, 1990.

CHAVEIRO, Eguimar Felício. A captura do território goiano e a sua múltipla dimensão sócio-espacial. In: CHAVEIRO, Eguimar Felício (org.). Traços, linhas matrizes para a compreensão de um Goiás profundo. Goiânia: Modelo, 2005. p. 168-185.

DALCASTAGNÉ, Regina. Uma voz ao sol: representação e legitimidade na narrativa brasileira contemporânea. Estudos de Literatura Brasileira Contemporânea. Brasília, n. 20, p. 33-77, jul/ago. 2002.

FELÍ́CIO, Brasigóis. Diários de André. Goiânia: Oriente, 1974. 
. Escrito no muro. Goiânia: Edições da Parte Viva, 1980.

. Viver é devagar. Goiânia: Asa, 2003.

FREIRE, Cristina. Além dos mapas: os monumentos no imaginário urbano contemporâneo. São Paulo: Sesc: Annablume, 1997.

LEFEBVRE, Henri. O direito à cidade. Tradução de Rubens Eduardo Frias. São Paulo: Moraes, 1991.

LUKÁCS, Georg. Ensaios sobre literatura. 2. ed. Rio de Janeiro: Civilização Brasileira, 1968.

MARX, Karl. Só a educação dos sentidos permitiu o nascimento das artes. In: Marx, Karl; ENGELS, Friedrich. Sobre literatura e arte. Tradução de Olinto Beckerman. São Paulo: Global, 1979.

MIRANDA, Mônica G. Representações do espaço urbano e a revelação do sujeito geográfico: um estudo com jovens de Ceilândia-DF. 2006. Dissertação (Mestrado em Educação) - Universidade de Brasília (UnB), Brasília.

MONTEIRO, Carlos Augusto de Figueiredo. O mapa e a trama: ensaios sobre o conteúdo geográfico em criações romanescas. Florianópolis: Ed. da UFSC, 2002.

MOSCOVICI, Serge. Representações sociais: investigação em psicologia social. 4. ed. Tradução de Pedrinho A. Guareschi. Petrópolis: Vozes, 2003.

PERSICANO, Maria Luiza Scrosoppi. Criatividade e subjetivação: do cérebro à arte na criação do humano. In: BARTUCCI, Giovana (org.). Psicanálise, arte e estéticas de subjetivação. Rio de Janeiro: Imago, 2002, p. 177-198.

RAMOS, Nuno. Minuano. In: BARTUCCI, Giovanna (Org.). Psicanálise, arte e estética de subjetivação. Rio de Janeiro: Imago, 2002, p. 27-88.

REIGOTA, Marcos. Meio ambiente e representação social. 7. ed. São Paulo: Cortez, 2007.

RODRIGUES, Gilberto de Castro. Sussurros que grito. In: FERNANDES, Aparício (org.). Anuário de poetas do Brasil. Rio de Janeiro: Folha Carioca, 1978. p. 177-188.

RODRIGUES, Maria de Fátima Ferreira. A natureza e o lunário perpétuo no imaginário sertanejo. In: ALMEIDA, Maria Geralda, RATTS, Alecsandro J. P. (orgs.). Geografia: leituras culturais. Goiânia: Alternativa, 2003. p. 89-112.

SANTOS, Milton. Novos rumos da geografia brasileira. 2. ed. São Paulo: Hucitec, 1988.

SANTOS, Wendel. Crítica: uma ciência da literatura. Goiânia: Ed. da Universidade Federal de Goiás, 1983. 
SILVA, Valéria Cristina Pereira da. Representação das cidades. Formação, Presidente Prudente, n. 8, p. 75-86, 2001.

SUZUKI, Julio Cesar. Uma leitura da cidade na obra poética de Paulo Leminski. ANPEGE, Fortaleza, v. 2, p. 114-142, 2005.

VIGOTSKI, Lev Semionovitch. Psicologia da arte. São Paulo: Martins Fontes, 2001.

Recebido para publicação em junho de 2008

Aprovado para publicação em julho de 2008 